\title{
Winter rye yield depending on the types of fallows
}

\author{
Albert Kuzminykh*, Sergey Novoselov, Roman Eremeev \\ Mari state university, Yoshkar-Ola, Russia
}

\begin{abstract}
Winter rye is of great importance in strengthening and developing the grain economy of the Non-Chernozem region of Russia. In recent years, due to the high cost of fertilizers and plant protection products, agricultural producers have begun to pay more attention to the biologization of agriculture. One of the main means of biologizing agriculture is the use of sideration. The article presents the results of the research on the influence of pure, green-manured and occupied fallows on the growth and development of winter rye, crop contamination, soil microbiological activity and grain yield in the eastern part of the VolgaVyatka zone. It was revealed that the weather conditions of the growing season of the Republic of Mari El allowed the cultivation of winter rye on the green-manured fallow. With timely plowing of siderite, the amount of productive moisture in the soil before sowing winter crops is sufficient. The use of sideration improves the phytosanitary state of the agrocenosis - the contamination of winter rye crops when cultivated with green-manured fallow is significantly lower in comparison with cultivation with occupied fallow. Being a valuable food and energy material for the soil microflora, the plowed organic mass of green fertilizers contributes to a significant increase in the microbiological activity of the soil. The replacement of pure and occupied fallow with green-manured fallow cultivation of winter rye on this fallow allows you to get a significant increase in grain yield.
\end{abstract}

\section{Introduction}

Winter rye is of great importance in strengthening and developing the grain economy of the Non-Chernozem region of Russia. Its importance is especially increasing in areas where winter wheat cultivation is limited. Currently, the country's agriculture is experiencing a crisis, including the production of winter rye grain. So, over the past decade, the area of its sowing has decreased almost 2 times and has been maintained in the last three years at the level of 0.9-1.0 million hectares. In 2020 , the yield of winter rye was $2.44 \mathrm{t} / \mathrm{ha}$, and the gross grain harvest was 2375 thousand tons.

One of the reasons for the instability of high crop yields in the Non-Chernozem zone of Russia is the low level of soil fertility. In recent years, due to a sharp reduction in the use of fertilizers by farmers in the country, this problem has become even more urgent. Therefore, agronomic science began to pay more attention to the study of the problems of biologization of agriculture, which allows creating highly productive and environmentally sustainable agroecosystems, more fully and efficiently using the biocenotic potential of the agrocenosis and the natural resources of the region [1-3].

An important condition for obtaining high stable yields of agricultural crops is the correct choice of the predecessor. In the Non-Chernozem zone of the Russian Federation, winter rye is cultivated in crop rotations on pure, occupied and, less often, green-manured fallow, the value of which has begun to increase in recent years.
Fallows sideration, as an agrotechnical technique, can become the main direction of biologization of agriculture and obtaining high yields of agricultural crops [4-6].

\section{The purpose and methodology of research}

In order to study the effect of fallow precursors on the yield of winter rye in the conditions of the eastern part of the Volga-Vyatka zone, we conducted research in 20132015 in the experimental field of Mari State University. Winter rye was cultivated with relation to the crop rotation according to the following fallow predecessors:

1. Pure fallow (control).

2. Occupied fallow.

3. Green-manured fallow.

The soil of the experimental site is sod-podzolic medium loamy, the content of hydrolysis nitrogen was 63-80, mobile phosphorus - 220-238 and exchangeable potassium - 131-145 mg/kg, $\mathrm{pH}_{\text {sol }}$ - 6.0. The experiment was repeated three times. The repetitions were arranged in one tier; plots of land in them were systematic. The total area of the plot of land is 50; the area taken into account is $46 \mathrm{~m}^{2}$.

The technology of winter rye cultivation was generally accepted for the zone. Winter rye of the Tatiana variety was sown in the optimal time for the zone with a norm of 6.0 million pieces of germinating seeds per hectare. The treatment of pure fallow was

* Corresponding author: aliks06-71@mail.ru 
carried out according to the black type. In the occupied fallow using the green fertilizer, the vico-oat mixture was cultivated. Cleaning the fallow-raising crop and plowing the siderite were carried out a month before sowing the winter rye. With the biological mass of the green fertilizer, the soil received $232.5 \mathrm{~kg} / \mathrm{ha}$ of d.v. NPK. Observations, records and analyses were carried out according to the corresponding generally accepted methods.

\section{Results and Discussion}

One of the limiting factors in the cultivation of winter grain in the occupied fallow is that the fallow crops dry up the soil. This is especially obvious when it is harvested shortly before winter crops are sown. For the growth and development of most agricultural crops, the content of productive moisture in a meter layer of soil is considered very good if its amount is more than $160 \mathrm{~mm}$, good $-130 \ldots 160$, satisfactory $-90 \ldots 130$ and bad 60...90 mm [7].

We have studied the water regime of the soil of winter rye. On average, over the years of research before sowing winter rye, there was a sufficient amount of productive moisture in the meter layer of soil -155.8 $170.0 \mathrm{~mm}$, including in the arable layer $-30.5-33.3 \mathrm{~mm}$ (Figure 1).

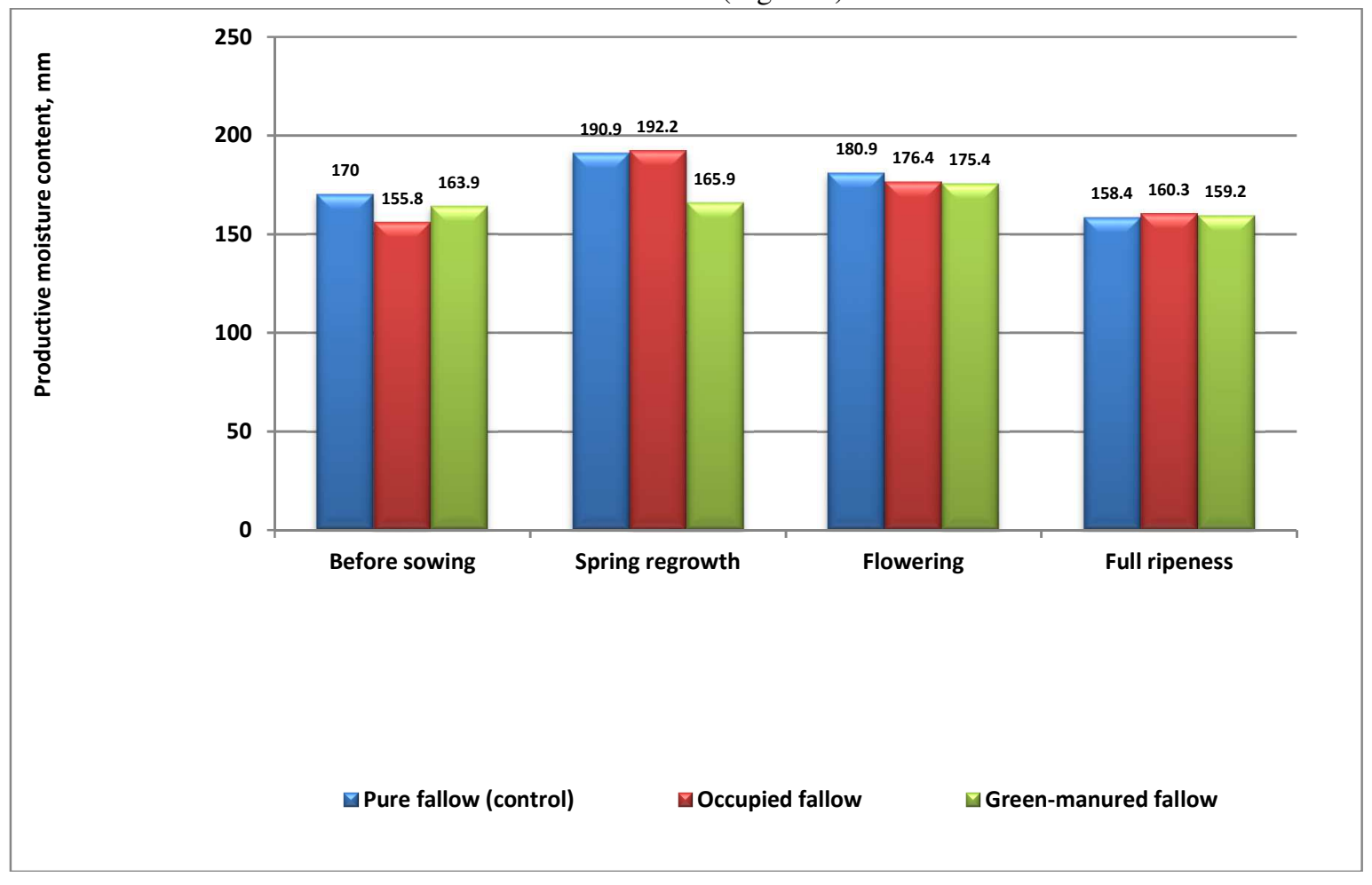

Fig. 1. Productive moisture content $(0-100 \mathrm{~cm}), \mathrm{mm}$

During the spring regrowth of winter rye, the amount of moisture on the experimental variants was 190.9$195.9 \mathrm{~mm}$. During the growing season of winter rye, the availability of productive moisture in the soil was also good, and in general, the difference in its content between the studied variants was insignificant.

The biological processes occurring in the soil, the intensity of which depends mainly on the quantity and quality of the organic matter entering it, are an important indicator of soil fertility [8-10]. The total activity of the soil biota can be estimated by the intensity of the decomposition of cellulose by cellulose-decomposing microorganisms. To determine the microbiological activity of the arable soil layer, we laid a linen cloth. The exposure period of flax was 60 days.

Studies have revealed that the microbiological activity of the soil was strong on winter rye crops cultivated on green-manured fallow. On average, over the years of research, the percentage of decomposed linen was $65.0 \%$ (Table 1). The results of the experiments showed that the use of green fertilizer significantly increases the microbiological activity of the soil. In comparison with the control pure fallow, sideration increased the degree of decomposition of linseed 1.46 times and occupied fallow -1.38 times.

Table 1. Microbiological activity of $0-20 \mathrm{~cm}$ of the soil layer

\begin{tabular}{|l|c|c|}
\hline \multicolumn{1}{|c|}{$\begin{array}{c}\text { Versions of the } \\
\text { experiments }\end{array}$} & $\begin{array}{c}\text { Proportion of } \\
\text { decomposed } \\
\text { tissue, } \%\end{array}$ & $\begin{array}{c}\text { Degree } \\
\text { of activity }\end{array}$ \\
\hline $\begin{array}{l}\text { Pure fallow } \\
\text { (control) }\end{array}$ & 44.5 & average \\
\hline $\begin{array}{l}\text { Occupied } \\
\text { fallow }\end{array}$ & 46.8 & average \\
\hline $\begin{array}{l}\text { Green-manured } \\
\text { fallow }\end{array}$ & 65.0 & strong \\
\hline SSD $_{05}$ & 13.3 & \\
\hline
\end{tabular}

The analysis of the research results of domestic and foreign scientists shows that the use of green fertilizers allows one not only to replenish the reserves of organic matter of the soil, improve its food regime, biological 
and physical properties, but also to improve the phytosanitary state of agrocenoses.

Taking into account the infestation of crops revealed that winter rye was mainly infested with perennial weeds. At the same time, rye cultivated with pure fallow was less clogged. So, on average, over the years of research, during the spring regrowth of winter rye, the number of weeds in this variant was $20.0 \mathrm{pcs} . / \mathrm{m}^{2}$ (Table 2).

Table 2. The contamination of winter rye crops, pieces $/ \mathrm{m}^{2}$

\begin{tabular}{|l|c|c|c|c|c|c|}
\hline \multirow{2}{*}{$\begin{array}{l}\text { Versions of } \\
\text { the } \\
\text { experiments }\end{array}$} & just & \multicolumn{3}{|c|}{ Spring regrowth } & \multicolumn{3}{|c|}{ amofore harvest } \\
\cline { 3 - 4 } \cline { 6 - 7 } & $\begin{array}{c}\text { juve } \\
\text { nile }\end{array}$ & $\begin{array}{c}\text { pere } \\
\text { nnial }\end{array}$ & just & $\begin{array}{c}\text { juven } \\
\text { ile }\end{array}$ & $\begin{array}{c}\text { peren } \\
\text { nial }\end{array}$ \\
\hline $\begin{array}{l}\text { Pure fallow } \\
\text { (control) }\end{array}$ & 20.0 & 4.0 & 16.0 & 10.3 & 2.0 & 8.3 \\
\hline $\begin{array}{l}\text { Occupied } \\
\text { fallow }\end{array}$ & 34.6 & 8.0 & 26.6 & 14.0 & 4.0 & 10.0 \\
\hline $\begin{array}{l}\text { Green- } \\
\text { manured } \\
\text { fallow }\end{array}$ & 30.6 & 7.6 & 23.0 & 12.0 & 2.0 & 10.0 \\
\hline SSD $_{05}$ & 3.9 & & & 1.8 & & \\
\hline
\end{tabular}

The analysis of the structure of weed vegetation showed that spring weeds included such weeds as Fumaria officinalis, Echinochloa crus-galli, Gálium aparíne, Veronica hederifolia, Centaurea cyanus, Matricaria perforata merat, Capsella bursa-pastoris and Thláspi arvénse. Among the perennial weeds, there was a spread of Convolvulus arvensis, Linaria vulgaris, Cirsium arvensis and Eguisetum arvense.

In the formation of the crop yield, the size and duration of the functioning of the leaf surface are important. Studies have shown that the maximum leaf surface of winter rye was formed during the earing phase - 41.7-50.1 thousand $\mathrm{m}^{2} / \mathrm{ha}$. When cultivating winter rye, it was the highest for the green-manured fallow. For occupied and control pure fallows, depending on the development phase, it was 12.1-35.0 \% lower. The photosynthetic potential of winter rye, depending on the variant, was 1648.3-2054.0 thousand $\mathrm{m}^{2}$ /haxday (Figure 2, 3).

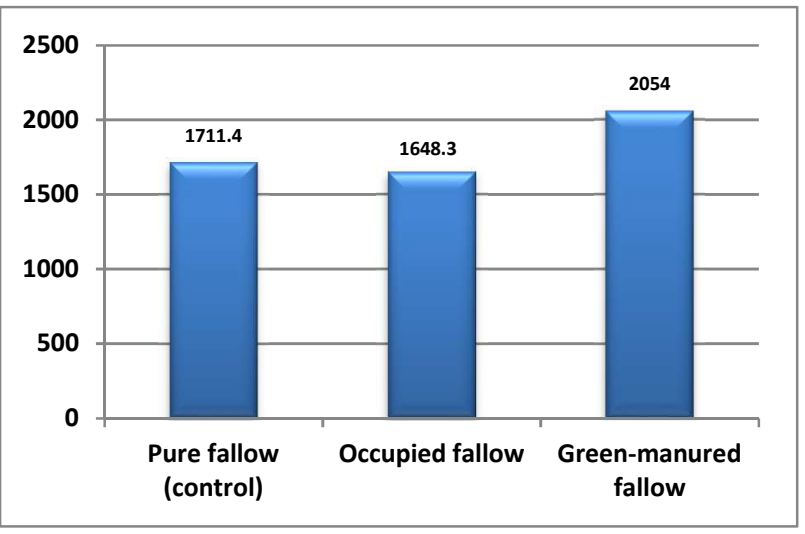

Fig. 2. Photosynthetic potential of winter rye (spring regrowth - full ripeness), thousand $\mathrm{m}^{2} /$ haxday.

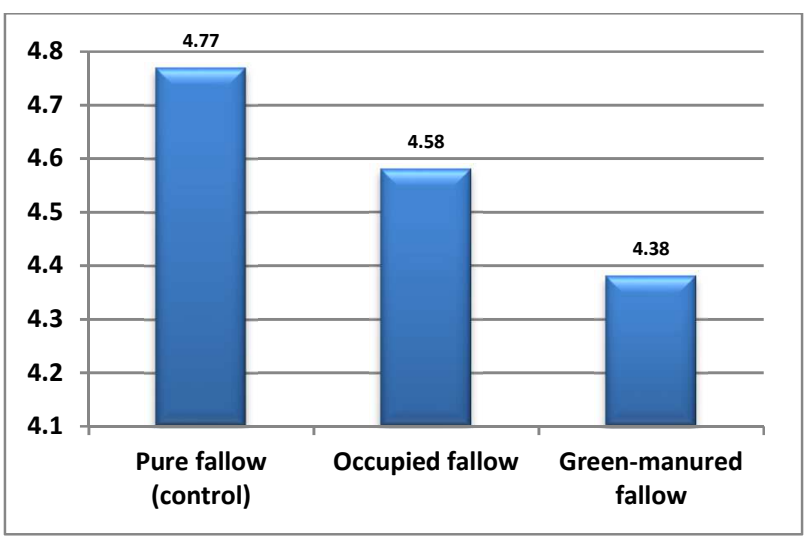

Fig. 3. Net photosynthetic productivity of winter rye (spring regrowth - full ripeness), $\mathrm{g} / \mathrm{m}^{2} \times$ day

At the same time, the higher photosynthetic potential was on the variant of winter rye cultivated by greenmanured fallow. For the options in case of the occupied and pure fallow, these were 19.8 and $16.7 \%$ lower, respectively. The net photosynthetic productivity of winter rye for the pure control fallow was the highest and amounted to $4.77 \mathrm{~g} / \mathrm{m}^{2} \times$ day, which was significantly $\left(\mathrm{SSD}_{05}=0.19 \mathrm{~g} / \mathrm{m}^{2} \times\right.$ day $)$ higher than this indicator of the other variants.

Table 3. The grain yield of winter rye

\begin{tabular}{|l|c|c|c|c|c|}
\hline \multirow{2}{*}{$\begin{array}{l}\text { Versions of } \\
\text { the } \\
\text { experiments }\end{array}$} & $\begin{array}{c}\text { Grain yield, } \mathrm{t} / \mathrm{ha} \\
\text { year }\end{array}$ & $\begin{array}{c}2014 \\
\text { year }\end{array}$ & $\begin{array}{c}2015 \\
\text { year }\end{array}$ & $\begin{array}{c}\text { avera } \\
\text { ge }\end{array}$ & $\begin{array}{c}\text { control, } \\
\text { t/ha }\end{array}$ \\
\cline { 2 - 5 } $\begin{array}{l}\text { Pure fallow } \\
\text { (control) }\end{array}$ & 4.12 & 3.55 & 2.92 & 3.53 & - \\
\hline $\begin{array}{l}\text { Occupied } \\
\text { fallow }\end{array}$ & 3.90 & 3.33 & 2.96 & 3.39 & -0.14 \\
\hline $\begin{array}{l}\text { Green- } \\
\text { manured } \\
\text { fallow }\end{array}$ & 4.60 & 3.81 & 3.20 & 3.87 & +0.34 \\
\hline SSD05 & 0.23 & 0.20 & 0.18 & 0.29 & \\
\hline
\end{tabular}

The results of the studies showed that a higher grain yield of winter rye, both in the years of research and on average, was obtained when it was cultivated using green-manured fallow. On average, over the three years of research, it was $3.87 \mathrm{t} /$ ha (Table 3 ).

The yield of winter rye grain in the other variants was significantly lower: $3.53 \mathrm{t} / \mathrm{ha}$ - when cultivated for pure control fallow and $3.39 \mathrm{t} / \mathrm{ha}$ - for occupied fallow.

The analysis of the crop structure revealed that the higher grain yield of winter rye, cultivated on the greenmanured fallow, is due to such elements of the structure as the number of plants per square meter -118.2 pcs., productive bushiness -3.7 , the number of grains in the ear - 45.9 pcs. and weight of 1000 grains - $30.1 \mathrm{~g}$ (Figure 4-7). In other variants, the indicators of the crop structure were slightly lower. 


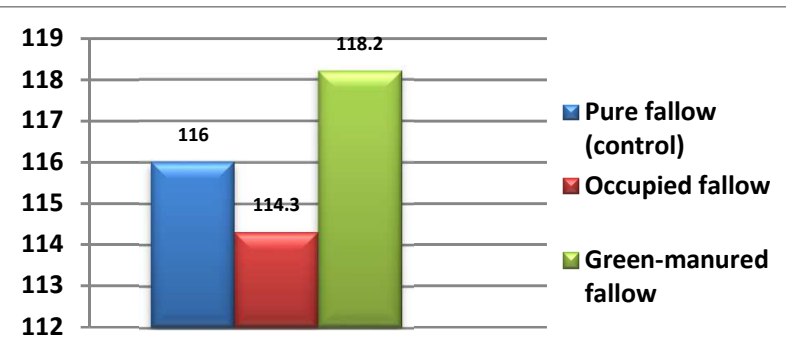

Fig. 4. Number of plants, pcs./square meter

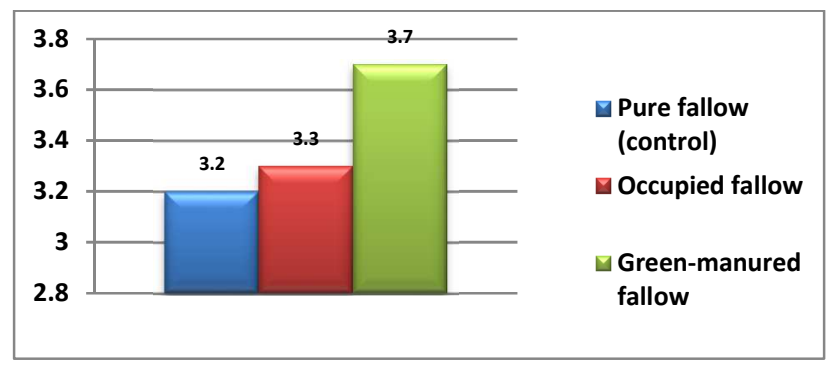

Fig. 5. Production of bushiness

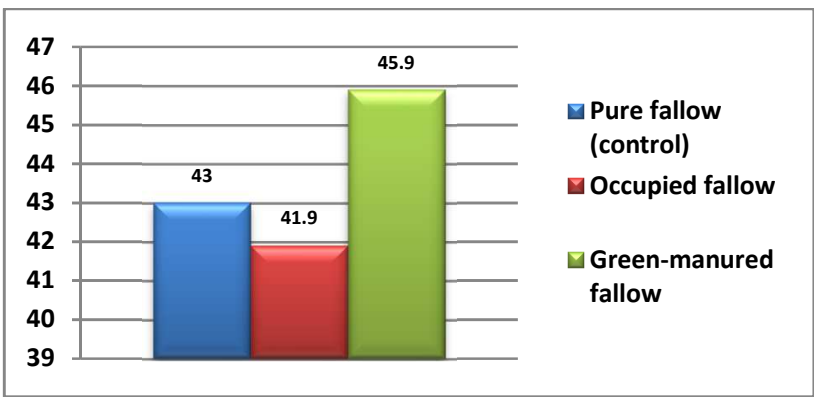

Fig. 6. The number of kernels per spike, pieces

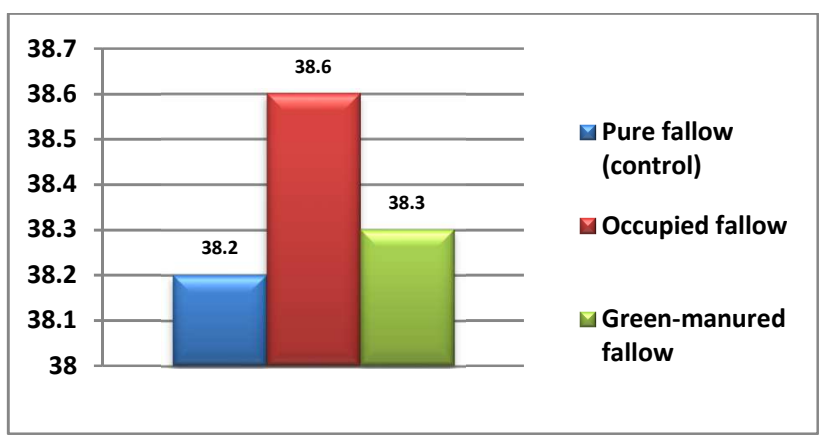

Fig. 7. Weight of 1000 grains, $g$

\section{Conclusion}

Thus, the obtained experimental data on the study of the effect of fallow precursors on the yield of winter rye in the conditions of the eastern part of the Volga-Vyatka zone allow us to draw the following conclusions:

1. The weather conditions of the growing season of the Republic of Mari El allow the cultivation of winter rye on the green-manured fallow. With timely plowing of siderite, the amount of productive moisture in the soil before sowing winter crops is sufficient.

2. The use of sideration improves the phytosanitary condition of the agrocenosis. The infestation of winter rye crops under cultivation by green-manured fallow is significantly lower in comparison with cultivation by occupied fallow.

3. Being a food and energy material for the soil microflora, the plowed organic mass of green fertilizers of green-manured fallow significantly increases the microbiological activity of the soil.

4. The replacement of pure and occupied fallow with green-manured fallow and cultivation of winter rye on its base allows you to get a significant increase in the grain yield.

\section{References}

1. S.I. Novoselov, A.N. Kuzminykh, R.V. Eremeev, The influence of fallow types and methods of primary tillage on soil fertility and productivity crop rotation, Fertility, 6 (2019)

2. S.I. Novoselov, N.I. Tolmachov, A.V. Murzhinova, The effect of mineral fertilizers on the productivity of crop rotations with different types of fallows, Fertility, 5 (2014)

3. M.Z. Alam, D.H. Lynch, M. Sharifi, D.L. Burton, A.M. Hammermeister, The effect of green manure and organic amendments on potato yield, nitrogen uptake and soil mineral nitrogen, Biol. Agric. Hortic., 32 (2016)

4. P.A. Postnikov, Green fertilizers - reserve for increasing yields, Agriculture, 10 (2010)

5. N.V. Shramko, G.V. Vikhoreva, Rational use of fallows and biologozation methods in the Upper Volga conditions, Agriculture, 6 (2015)

6. K. Miyazawa, T. Murakami, M. Takeda, T. Murayama, Intercropping green manure crops Effects on rooting patterns, Plant Soil, 331 (2009)

7. A.F. Vadyunina, Z.A. Korchagina, Methods of research of physical properties of the soil (Moscow, Agropromizdat, 1986)

8. A.N. Kuzminykh, Siderites - an important resource of soil fertility maintenance, Agriculture, 4 (2011)

9. R.B. Froseth, A.K. Bakken, M.A. Bleken, H. Riley, R. Pommeresche, K. Thorup-Kristensen, S. Hansen, Effects of green manure herbage management and its digestate from biogas production on barley yield, N-recovery, soil structure and earthworm populations, Eur. J. Agron., 52 (2014)

10. M. Tejada, J.L. Gonzalez, A.M. García-Martínez, J. Parrado, Application of a green manure and green manure composted with beet vinasse on soil restoration: Effects on soil properties, Bioresour. Technol., 99 (2008) 